\title{
HUBUNGAN KADA HAEMOGLOBIN (HB) DENGAN KAPASITAS AEROBIK MAKSIMAL PADA SANTRI PONDOK PESANTREN TAPAK SUNAN JAKARTA
}

\author{
Ma'mun Irsyadi', \\ Dr. Yasep Setiakarnawijaya, SKM, M.Kes ${ }^{2}$, Drs. Hidayat Humaid, M.Pd ${ }^{2}$ \\ ${ }^{1}$ Program Studi Ilmu Keolahragaan \\ ${ }^{2}$ Fakultas Ilmu Keolahragaan Universitas Negeri Jakarta, Kampus B, Jakarta
}

\begin{abstract}
Abstrak: Penelitian ini bertujuan untuk memperoleh informasi tentang Hubungan Kadar Hemoglobin Terhadap Kapasitas Aerobik Maksimal baik secara sendiri-sendiri maupun bersama-sama. Penelitian ini dilakukan di lapangan Pondok Pesantren Tapak Sunan J1. Kayu manis amd 28 Rt 03/05 Condet Balekambang Jakarta Timur, Minggu, 18 November 2012. Penelitian ini menggunakan survey dengan teknik korelasional. Sampel yang digunakan yaitu Santri Pondok Pesantren Tapak Sunan Jakarta. Pengambilan sempel dengan menggunakan purposive sampling, pengujian hipotesis menggunakan analisis statistikakorelasi sederhana, yang dilanjutkan dengan uji-t pada taraf signifikasi $\alpha=0.05$. Hasil penelitian menunjukan : Terdapat hubungan yang bermakna antara Kadar Hemoglobin terhadap Kapasitas Aerobik Maksimal dengan persamaan regresi $\mathrm{Y}=8.618+2.349 \mathrm{X}$. Artinya Kapasitas Aerobik Maksimal dapat diketahui atau diperkirakan dengan persamaan regresi tersebut jika variabel Kadar Hemoglobin (X) diketahui. Koefisien korelasi $(\mathrm{r})=0.484$, $\mathrm{t}$ hitung $=$ 2.652 , $\mathrm{t}$ tabel $=2.069$, terlihat bahwa $\mathrm{t}$ hitung $>\mathrm{t}$ tabel yang menunjukkan bahwa hipotesis nihil $\left(\mathrm{H}_{0}\right)$ ditolak dan hipotesis alternatif $(\mathrm{H} l)$ diterima dengan koefisien determinasi $\mathrm{r}^{2}=0.234$. Hal ini berarti bahwa $23.4 \%$ kapasitas aerobik maksimal dipengaruhi oleh hemoglobin, sedangkan $76.6 \%$ variasi (bisa dipengaruhi oleh faktor lain).
\end{abstract}

Kata kunci: Haemoglobin, kapasitas aerobic maksimal, sentri pondok pesantren.

\section{PENDAHULUAN}

Pesantren pada mulanya merupakan pusat pembelajaran nilai-nilai dan penyiaran agama Islam. Namun, dalam perkembangannya, lembaga ini semakin memperlebar pendidikan yang tidak selalu memfokuskan materi- materi keagamaan, tetapi juga kesadaran sosial atau umum. Dengan demikian, pesantren tidak bisa lagi disebut semata-mata sebagai lembaga keagamaan murni, tetapi juga menjadi lembaga sosial yang hidup yang terus berkaitan persoalan dengan masyarakat di sekitarnya.

Pondok Pesantren Tapak Sunan sebagai salah satu Lembaga Pendidikan Islam yang terletak di Condet Balekambang Jakarta Timur, berkiprah dan ikut berperan serta dalam usaha mencerdaskan kehidupan bangsa dan mengembangkan manusia seutuhnya yang beriman, bertakwa dengan mengamalkan kegamaan yang konsisten/ istiqomah, berbudi luhur/akhlaqul karimah, memilki pengetahuan dan keterampilan yang memadai, sehat jasmani dan rohani, berkepribadian mantap, mandiri dan bertanggung jawab terhadap diri, keluarga dan masyarakat. Santri-santri Tapak sunan meskipun tinggal di lingkungan asrama pondok pesantren, yang segala aktifitasnya diatur oleh pondok pesantren tersebut dari segala macam kegiatan, seperti asupan makanan, istirahat, Dan juga Kegiatan di pondok pesantren lebih banyak duduk, mengaji, shalat, sedangkan kegiatan olahraga hanya dilakukan setiap hari sabtu bukan berarti santri ketinggalan jaman, tetapi mereka 
sudah mengenal jenis-jenis olahraga, kesenian, pariwisata dan lain sebagainya. MTs Tapak Sunan contoh nya para pelajar sering mendapatkan mendali emas di cabang olahraga tenis meja, senam irama dalam kejuaraan POSPEDA dan POSPENAS yang sering diadakan setiap tahun.

Prestasi yang telah diraih oleh santri tapak sunan telah menunjukkan bahwa untuk mencapai keberhasilan dalam cabang-cabang olahraga ini membutuhkan fisik, teknik dan mental yang merupakan syarat utama agar dapat berprestasi maksimal. Aspek kondisi fisik adalah salah satu komponen- komponen yang tidak bisa dipisahkan begitu saja, baik peningkatan maupun pemeliharaannya. Untuk meningkatkan kesegaran jasmani perlu diketahui komponen- komponen dari kesegaran jasmani. Komponen-komponen kesegaran jasmani yang berhubungan dengan kesehatan adalah meliputi daya tahan jantung, paru, kekuatan otot, daya tahan otot fleksibilitas dan komposisi tubuh.

Dari komponen-komponen tersebut dapat dipahami bahwa kesegaran jasmani seseorang dapat diukur melalui salah satu komponennya yaitu daya tahan jantung. Daya jantung merupakan kemampuan sejumlah besar otot untuk melakukan kerja fisik secara terus-menerus dalam waktu tertentu. Hal ini merupakan kemampuan sistem peredaran darah dan sistem pernafasan untuk menyesuaikan diri terhadap efek seluruh beban kerja fisik. Istilah daya tahan jantung sering juga disebut daya tahan kardiorespirasi, kapasitas aerobik, maximal aerobik power dan sebagainya.

Daya tahan jantung merupakan kemampuan sejumlah besar otot untuk melakukan kerja fisik secara terus menerus dalam waktu tertentu atau merupakan kemampuan sistem pernafasan dan sistem sirkulasi darah untuk menyesuaikan diri terhadap efek seluruh beban kerja fisik. Secara lebih spesifik hal ini merupakan kemampuan menghirup oksigen dari atmofsir kedalam paru-paru dan kemudian darah memompanya melalui jantung ke otot yang berkerja dimana oksigen digunakan untuk memengoksidasi karbohidrat dan lemak untuk menghasilkan energy. Disinilah peran oksigen sangat diperlukan. Peran tersebut membutuhkan peran komponen lain dalam sirkulasi yaitu sel darah. Menurut Soedjono ada tiga jenis utama sel darah yaitu sel darah merah (erirosit), sel darah putih (leukosit), dan keeping darah (trombosit). Kemudian Soedjono juga menjelaskan bahwa salah satu jenis darah tersebut (eritrosit) berfungsi mengangkut gas-gas pernafasan, oksigen dan karbondioksida. Untuk dapat mengangkut gas-gas pernafasan tersebut didalam eritrosit terdapat hemoglobin $(\mathrm{Hb}) . \quad \mathrm{Hb}$ (hemoglobin) atau dalam bahasa indonesianya dikenal sebagai protein darah merupakan komponen darah yang berfungsi untuk mengikat oksigen dan menyebarkannya keseluruh jaringan tubuh serta mengikat karbondioksida dari seluruh tubuh dan membawanya kembali ke paru-paru.

Menurut istilah hemoglobin berasal dari dua buah kata yakni "heme" atau zat pemberi warna merah dan protein "globin", kedua zat tersebut bergabung menjadi hemoglobin. Hemoglobin adalah salah satu komponen kimia yang terdapat pada sel darah merah (eritrosit). Melihat kenyataan yang ada diatas peneliti berkeinginan untuk mengadakan suatu penelitian untuk meningkatkan kualitas kesegaran jasmani, yaitu kadar hemoglobin $(\mathrm{Hb})$ dalam darah yang berhubungan dengan kapasitas aerobik maksimal. Adapun alasan penulis mengadakan penelitian tentang kadar hemoglobin dan kapasitas aerobik maksimal (VO2 max) adalah karena dua komponen tersebut merupakan komponenkomponen fisik yang perlu ditingkatkan dalam meningkatkan kesegaran jasmani.

Tinjauan Pustaka. Menurut istilah hemoglobin berasal dari dua buah kata yakni "heme" atau zat pemberi warna 
merah dan protein "globin". Kedua zat tersebut bergabung menjadi hemoglobin. Hemoglobin adalah salah satu komponen kimia yang terdapat pada sel darah merah (eritrosit).

Dalam melakukan aktivitas manusia memerlukan oksigen. Oksigen yang dihirup manusia kemudian disebarkan ke berjuta-juta sel diseluruh tubuh untuk digunakan sebagai sumber energi. Untuk menyebarkan oksigen dan zat-zat yang diperlukan oleh sel-sel tubuh, di dalam tubuh kita terjadi suatu proses yang dinamakan sistem sirkulasi.

Menurut Soedjono dalam bukunya Anatomi dan Fisiologi Manusia, Sistem Sirkulasi merupakan sistem yang berfungsi yang mengangkut berbagai subtansi menuju dan dari sel-sel tubuh. Salah satu komponen dalam sirkulasi adalah darah. Menurut Soedjono ada tiga jenis utama sel darah yaitu sel darah merah (eritrosit), sel darah putih (leukosit), dan keeping darah (trombosit). Kemudian Soedjono juga menjelaskan bahwa salah satu jenis darah tersebut (eritrosit) berfungsi mengangkut gas-gas pernafasan, oksigen dan karbondioksida. Untuk dapat mengangkut gas-gas pernafasan tersebut di dalam eritrosit terdapat hemoglobin $(\mathrm{Hb})$.

Molekul Hemoglobin terdiri dari dua bagian: (1) bagian Globin, suatu protein yang berbentuk dari empat rantai polipeptida yang sangat berlipat- lipat, dan (2) gugus nitrogenosa non prosdin mengandung besi yang yang dikenal sebagai gugus hem (heme), yang masingmasing terikat ke satu polipeptida. Melalui buku penuntun praktikum faal dasar dijelaskan: Hemoglobin ( $\mathrm{Hb})$ merupakan zat bewarna merah pembawa oksigen dan karbon dioksida didalam sel darah merah. $\mathrm{Hb}$ merupakan gugus protein yang mengandung ferro (besi). Tiap gr $\mathrm{Hb}$ mengandung 1,34 $\mathrm{ml}$ oksigen, konsentrasi $\mathrm{Hb}$ dalam darah kira-kira $15 \mathrm{gr} \%$ (pada wanita $14 \mathrm{gr} \%$ dan pria $16 \mathrm{gr} \%$ ) ini artinya didalam $100 \mathrm{cc}$ darah mengandung $15 \mathrm{gr}$ $\mathrm{Hb}$ atau 15 kali 1,34 ml oksigen yang berikatan dengan $\mathrm{Hb}$.
Dari keterangan beberapa sumber diatas di pahami bahwa hemoglobin adalah sebuah protein yang berada pada sel darah merah yang kadarnya berbeda pada pria dan wanita. Merupakan gabungan antara protein heme dan globin yang dapat bergabung dengan oksigen yang berfungsi membawa atau mengirimkan oksigen dari paru-paru menuju jaringan-jaringan tubuh. Dan juga hemoglobin memberikan warna merah pada sel darah merah berarti bahwa semakin pekat warna merah yang terdapat pada sel darah merah berarti semakin banyak oksigen yang terkandung didalamnya. Guyton juga menjelaskan bahwa adanya hemoglobin memungkinkan sel darah merah mengangkut oksigen yang ditranspor dalam bentuk cairan darah.

Telah dijelaskan bahwa hemoglobin dalam darah mengikat oksigen dan membawa oksigen tersebut dari paru-paru keseluruh tubuh. Daya ikat atau afinitas hemoglobin dipengaruhi oleh beberapa faktor, menurut Ganong faktor-faktor tersebut adalah $\mathrm{pH}$, suhu, dan konsentrasi 2,3-disfosfogliserat. Selain faktor-faktor tersebut, Guyton juga menambahkan peningkatan konsentrasi $\mathrm{CO} 2$ juga berpengaruh pada afinitas hemoglobin terhadap oksigen. Kadar hemoglobin yang normal pada pria antara 13,5-18 gr\% dan wanita sebesar 11,5-16 gr\%.

Selain memahami beberapa keterangan diatas, jadi jelaslah bahwa hemoglobin sangat berperan penting dalam transport oksigen ke jaringan- jaringan yang ada di tubuh yang mana oksigen tersebut sangat dibutuhkan oleh sel-sel dalam tubuh ketika melakukan aktivitas fisik.

Kapasitas Aerobik Maksimal. Menurut Russel Pate, kemampuan kapasitas aerobik maksimal (VO2max) adalah tempo tercepat dimana seseorang dapat menggunakan oksigen sela kesegaran jasmani adalah kemampuan seseorang untuk melakukan tugasnya sehari-hari dengan gampang, 
tanpa merasa lelah yang berlebihan, dan masih mempunyai sisa atau cadangan tenaga untuk menikmati waktu senggangnya untuk keperluan yang mendadak. Sedangkan menurut pendapat lain menjelaskan bahwa, kapasitas aerobik maksimal adalah jumlah maksimal oksigen yang dapat diolah tubuh dalam waktu tertentu. VO2max adalah kemampuan untuk mengambil oksigen selama kerja fisik, VO2max yang dinyatakan dalam liter/ menit.

Sistem sirkulasi adalah sistem transpor yang mengantarkan $\mathrm{O}_{2}$ dan berbagai zat-zat yang diabsorbsi dari trakus gastrointestinal menuju ke jaringan serta mengembalikan $\mathrm{CO} 2$ ke paru-paru dan hasil metabolisme lain ke ginjal. Sistem sirkulasi juga berperan dalam pengaturan suhu tubuh, dan mendistribusikan hormone serta berbagai zat lain yang mengatur fungsi sel.

Pada setiap makhluk hidup pasti ada suatu metabolisme maupun proses lainnya, apalagi makhluk yang memiliki banyak jaringan. Jantung adalah organ berongga empat yang berfungsi memompa darah lewat sistem pembuluh darah. Jantung menggerakkan darah dengan kontraksi yang kuat dan teratur dari serabut otot yang membentuk dinding rongga-rongganya. Ditinjau dari segi latihan olahraga, rongga jantung yang terpenting adalah ventrikel kiri, karena rongga ini memompa darah yang mengandung oksigen ke seluruh organ dan jaringan tubuh, termasuk otot rangka. Untuk kepentingan tersebut dibutuhkan suatu sistem untuk mengangkut (transportasi). Pada manusia sistem tersebut disebut sistem sirkulasi.

Sistem sirkulasi berguna untuk keperluan mengangkut zat-zat makan dari usus dan juga hasil metabolisme tubuh untuk dibuang pada alat pembuangan. Untuk tugas sirkulasi dibutuhkan suatu sistem pompa, tempat untuk mengalirkannya berupa pembuluh darah dan benda yang dialirkannya yaitu darah. Jadi prinsip peredaran darah ialah: ada pompa pengedar, ada cairan/ zat yang diedarkan, dan ada tempat beredarnya, dengan demikian fungsi utama dari sirkulasi adalah transportasi, selain pertahanan tubuh/proteksi tubuh. Dalam peredaran darah dibedakan: 1. Pompa: berupa jantung, 2. Pembuluh: arteri dan vena, 3. benda yang diedarkan: darah dan plasma. Jadi dalam hal ini jantung merupakan pompa yang bekerja secara otomatis dan tidak dipengaruhi kehendak kita. Menurut Lauralee Sherwood, dalam bukunya Fisiologi Manusia dari sel ke sistem edisi 2, dijelaskan bahwa: Sistem sirkulasi berperan dalam homestatis yang berfungsi sebagai sistem transportasi tubuh. Pembuluh darah mengangkut dan mendistribusikan darah yang dipompa oleh jantung untuk memenuhi kebutuhan tubuh aka $\mathrm{O} 2$ dan nutrient, menyingkirkan zat sisa dan penyampaian sinyal hormon. Jantung terletak di rongga dada diantara paru-paru kanan dan kiri, jantung merupakan pompa dari sistem sirkulasi darah dan dibagi menjadi 4 ruangan: Atrium (serambi), kanan dan kiri dibatasi dengan sekatdan ventrikel kanan dan kiri. Dari atrium kanan darah mengalir melalui celah dan klep (valvula) tricuspidalis. Dari atrium kiri ke ventrikel kiri darah mengalir melalui celah dan klep bicuspidalis.

Pada manusia mekanisme pompa terjadi melalui sistem pompa. Yaitu sirkulasi utama (sistemik) dan sirkulasi kecil (pulmonal). Sirkulasi utama, dari ventrikel kiri darah di pompa melalui arteri dan arteriola menuju ke kapiler tempat terjadinya imbangan dengan cairan interstisial. Dari kapiler, darah dikembalikan melalui venula dan vena ke dalam atrium kanan. Sirkulasi kecil (pulmonal), dari atrium kanan darah mengalir ke ventrikel kanan, yang memompa darah melalui pembuluh darah paru, kembali ke atrium kiri kemudian masuk ke ventrikel kiri.

Volume darah yang dipompakan ke dalam nadi utama oleh ventrikel jantung, pada umumnya dinyatakan sebagai liter 
per menit disebut curah jantung (cardio output). Sedangkan volume darah yang dipompakan oleh ventrikel per denyut disebut sekucup (stroke volume). Stroke volume biasanya dikalkulasi dengan membagi cardiac output dengan denyut jantung. Sehingga bisa didapat rumus cardiac output $=$ stroke volume (SV) $\mathrm{x}$ denyut jantung. Pembuluh darah adalah suatu sistem saluran tertutup yang membawa darah dari jantung ke jaringan dan kembali lagi ke jantung. Ada tiga jenis pembuluh darah yang utama, yaitu: arteri yang membawa darah keluar jantung, kapiler yang merupakan selaput kecil untuk pertukaran sebagai zat, dan vena yang mengembalikan darah dari kapiler ke atrium kanan jantung.

Kalau kita urutkan jalan darah di pembuluh darah maka darah pertama dari aorta (pembuluh besar yang keluar dari ventrikel kiri) bercabang menjadi arteri besar kemudian arteri kecil dan di jaringan bercabang menjadi arteriola kemudian mitarteriola (kapiler) yang dindingnya hanya selapis bersatu menjadi venula, venula-venula bersatu menjadi vena, vena bersatu dengan vena yang lain menjadi vena besar, menuju ke jantung dan akhirnya bermuara di atrium kanan.

Seseorang yang memiliki kesegaran jasmani yang baik akan dapat mengatasi beban kerja fisik tanpa menimbulkan kelelahan yang berarti, bahkan mempunyai tenaga cadangan untuk sewaktu-waktu digunakan secara darurat. Oleh sebab itu kesegaran jasmani yang baik dapat kita peroleh dengan melakukan olahraga teratur. Kesegaran jasmani adalah kemampuan seseorang untuk meakukan tugasnya sehari-hari dengan gampang, tanpa merasa lelah yang berlebihan, dan masih mempunyai sisa atau cadangan tenaga untuk menikmati waktu senggangnya untuk keperluan yang mendadak. Sedangkan menurut pendapat lain menjelaskan bahwa, kapasitas aerobik maksimal adalah jumlah maksimal oksigen yang dapat diolah tubuh dalam waktu tertentu. VO2max adalah kemampuan untuk mengambil oksigen selama kerja fisik, VO2max yang dinyatakan dalam liter/menit.

Pengukuran banyaknya udara atau oksigen disebut VO2 Max, V berarti volume $\mathrm{O} 2$ berarti oksigen, $\max$ berarti maksimum, dengan demikian $\mathrm{VO}_{2} \mathrm{Max}$ berarti oksigen yang dapat digunakan oleh tubuh saat bekerja. Menurut Rasel Pate beberapa faktor yang mempengaruhi kapasitas aerobik maksimal, antara lain :

a. Fungsi paru-paru dan jantung

Olahraga berat biasanya disertai dengan penyesuaian yang nyata dalam fungsi paru-paru dan jantung, respon tersebut dimungkinkan dengan peningkatan kebutuhan oksigen melalui otot-otot rangka yang bekerja. Pertukaran udara komponen penting dari proses pengangkutan oksigen, oksigen disalurkan melalui sel darah merah. Kita telah mengetahui bahwa kebugaran aerobik sangat berkaitan dengan total hemoglobin dan bahwa volume darah dan hemoglobin meningkat dengan latihan.

Seperti diketahui bersama bahwa kebugaran jantung dan paru-paru adalah kemampuan jantung dan paru-paru dalam memenuhi kebutuhan $\mathrm{O} 2$ dan nutrisi di otot rangka terutama otot-otot besar, agar otot-otot tersebut dapat bekerja maksimal dalam jangka waktu yang lama. Kebugaran jantung dan paruparu merupakan komponen terpenting dalam kesegaran kerja fisik yang cukup oksigen. Jantung yang terlatih memompa lebih banyak darah setiap kali berdenyut. Jantung adalah pompa yang mengeluarkan darah yang memasuki serambinya, masukan lebih banyak darah kedalam serambinya dan lebih banyak lagi keluar. Jadi kapasitas fungsionanal paru-paru dan jantung adalah kunci penentu dari $\mathrm{VO} 2$ max seseorang .

b. Metabolisme Otot Aerobik

Respon fisiologis dasar terhadap kerja fisik berupa laju peningkatan penggunaan ATP dalam serabut otot rangka, serabut otot rangka adalah sel-sel yang teratur dengan sangat baik dan bersifat khusus 
yang berfungsi sebagai penghasil kekuatan melalui kontraksi. Sel serabut rangka ini sering di sebut Sarkolemma yang mengatur jalannya zat-zat kimia kedalam dan keluar sel. Dengan efesiensi dan besarnya kapasitas sistem metabolic menjadi sumber ATP yang dikehendaki otot, tetapi laju regenerasi ATP secara aerobik dibatasi oleh laju pengiriman oksigen oleh sistem paru jantung ke otot-otot aktif. Karena metabolisme otot aerobik hanya dapat terjadi dengan penggunaan oksigen, laju pemakaian oksigen tubuh adalah gambaran mutlak dari laju metabolisme aerobiknya.

Berdasarkan uraian tersebut maka kapasitas aerobik maksimal (VO2max) merupakan unsur kemampuan kondisi fisik yang tidak bisa diabaikan dalam mencapai hasil latihan, karena VO2max juga merupakan gambaran kemampuan otot rangka untuk menyadap oksigen dari darah dan menggunakannya dalam metabolisme aerobik.

Jadi dapat disimpulkan bahwa metabolisme otot aerobik tidak bisa diabaikan begitu saja, karena setiap olahragawan dapat mempunyai nilai VO2max tinggi hanya, apabila otot rangka mereka dapat menggunakan oksigen secara cepat dalam metabolisme aerobik.

\section{c. Kegemukan badan}

Jaringan lemak menambah berat badan, tetapi tidak mendukung kemampuan olahragawan secara langsung menggunakan oksigen selama olahraga berat. Jadi kegemukan badan cenderung mengurangi berat relative $\mathrm{VO} 2 \mathrm{max}$ dan kapasitas fungsional dengan menambah berat badan, dengan kata lain jika lemak meningkat maka VO2 max seseorang akan menurun.

\section{d. Latihan}

Efek langsung dari latihan atau aktivitas olahraga/kerja fisik yang paling dirasakan adalah meningkatnya derajat jantung dan frekuensi pernafasan, sebagai reaksi adaptasi dari tubuhnya akan terjadi beberapa perubahan penting pada sistem jantung dan peredaran darah, seperti peningkatan tegangan otot polos dari arter, peningkatan daya difusi oksigen, dan karbondioksida dalam kapiler paru-paru dan jaringan lainnya, peningkatan volume kuncupan jantung dan meningkatnya denyut jantung maksimum. Jadi dapat diketahui bahwa dengan melakukan kerja fisik secara progesif dapat meningkatkan VO2max seseorang.

e. Keturunan

Faktor keturunan sangat berpengaruh sekali dalam upaya maeningkatkan VO2max. VO2max seseorang hanya dapat ditingkatkan dengan latihan yang progresif dan berintensitas tinggi. Tetapi meskipun demikian dengan latihan pun VO2max hanya dapat meningkat sebesar 10 hingga $20 \%$ saja. Maka dari itu VO2max setiap individu tidak sama besarnya atau berbedabeda, karena perbedaan garis keturunan .

Daya tahan kardiorespirasi adalah seberapa baik anda mampu menghirup oksigen dari atmofsir ke dalam paru-paru dan kemudian darah, dan kemudian memompanya melalui jantung ke otot yang bekerja dimana oksigen digunakan untuk mengoksidasi karbohidrat dan lemak untuk menghasilkan energi.

Dalam buku penuntun praktikum ilmu faal kerja (ergofisiology) dijelaskan bahwa: kapasitas aerobik adalah suatu kualitas yang memungkinkan kita mampu melaksanakan secara terusmenerus selama mungkin suatu kerja fisik yang akan bersifat umum dalam kondisi aerobik (cukup oksigen). Dari pengertian diatas dapat disimpulkan bahwa seseorang memiliki daya tahan kardiorespirasi yang baik maka ia mampu melaksanakan suatu kerja otot secara terusmenerus dalam keadaan yang cukup oksigen. Daya tahan kardiorespiresi (VO2max) diukur dalam bentuk jumlah mil liter oksigen yang dikonsumsikan per $\mathrm{Kg}$ berat badan dalam setiap menit.

f. Genetik

Gabe Mirkin dan Marshal Hofman mengatan : kemampuan maksimal tubuh anda untuk mengangkut oksigen ke otot 
dibatasi oleh sifat genetik anda dan sangat bervariasi dari satu individu ke individu lainnya. Didalam setengah perbedaan VO2max dikarenakan oleh perbedaan Genotype. Astrand dan Rodhal pun sependapat bahwa "bantuan alami (faktor genetik) memainkan peranan penting dalam $\mathrm{VO} 2 \mathrm{max}$ seseorang".

g. Jenis kelamin

Rata-rata wanita muda memiliki kapasitas aerobik antara 15 hingga 25\% lebih kecil dari pria muda, tergantung pada tingkat aktivitasnya, dan satu alasan perbedaan antara jenis kelamin adalah hemoglobin, rata-rata pria memiliki kirakira 2gr lebih per 100 mililiter darah, dan total hemoglobin berkaitan dengan VO2 daya tahan. Kadar hemoglobin yang normal pada pria antara 13,5-18gr\% dan pada wanita sebesar 11,5-16gr\%.

h. Usia

VO2 max pria dan wanita mempunyai masa puncaknya pada usia 18 sampai 20 tahun dan perlahan akan menurun, dan ketika berusia 65 tahun ratarata nilai VO2 amax sekitar $70 \%$ dari VO2max yang dicapai pada saat berusia 25 tahun secara individu. Efek usia terhadap kesegaraan jasmani untuk individu yang tidak aktif $\mathrm{VO} 2 \mathrm{max}$ akan mengalami penurunan 8 hingga $10 \%$ per dekade (per 10 tahun). Bagi individu yang aktif dapat menghentikan setengah penurunan tersebut 4 hingga $5 \%$ per dekade.

\section{i. Komposisi tubuh}

Walaupun VO2max dinyatakan dalam beberapa milliliter oksigen per $\mathrm{Kg}$ berat badan per menit, perbedaan komposisi tubuh seseorang menyebabkan konsumsi oksigen yang berbeda. Brian J Sharky mengemukakan bahwa VO2max seseorang dihitung per unit berat badan, jadi jika lemak meningkat, VO2max seseorang akan turun.

j. Latihan

Seseorang dapat memperbaiki VO2max dengan latihan daya tahan yang sistematis. Seperti yang dilakukan oleh Donald A. Mahler didalam buku ACSM (panduan uji latihan jasmani dan peresapannya edisi 5), mengatakan bahwa: peningkatan VO2max terbesar terjadi pada saat latihan melibatkan penggunaan kelompok otot besar dalam jangka waktu lama, berirama serta bersifat aerobik alami (misalnya, jalan kaki, hiking, lari, berenang, bersepeda, dayung, ergometri yang mengkombinasikan lengan dan kaki, menari (senam aerobik), skating, sky lintas alam, lompat tali, atau aktivitas permainan ketahanan.

Santri. Santri berarti orang yang mendalami agama islam, atau orang yang beribadah dengan sungguh-sungguh, atau bisa juga dengan orang yang shaleh. Santri juga bisa disebut sebagai murid yang mengikuti pendidikan di pondok pesantren. Pondok Pesantren adalah sekolah pendidikan umum yang persentasi ajarannya lebih banyak ilmu-ilmu pendidikan agama Islam. Kebanyakan muridnya tinggal di asrama yang disediakan di sekolah itu. Pondok Pesantren banyak berkembang di pulau Jawa. Pondok Pesantren Tapak Sunan sebagai salah satu Lembaga Pendidikan Islam yang terletak di Condet Balekambang Jakarta Timur, berkiprah dan ikut berperan serta dalam usaha mencerdaskan kehidupan bangsa dan mengembangkan manusia seutuhnya yang beriman, bertakwa dengan mengamalkan kegamaan yang konsisten/istiqomah, berbudi luhur/akhlaqul karimah, memilki pengetahuan dan keterampilan yang memadai, sehat jasmani dan rohani, berkepribadian mantap, mandiri dan bertanggung jawab terhadap diri, keluarga dan masyarakat.

Dalam kerangka pemikiran di atas, Pimpinan dan Pengasuh Pondok Pesantren Tapak Sunan, KH. Drs. Muhammad Nuruddin Munawwar telah membuka Pendidikan Salafiyah pada tahun 1990, kemudian mengembangkan pendidikan formal seperti Madrasah Tsanawiyah (MTs) pada tahun 1993 dan membuka Madrasah Aliyah (MA) pada 
tahun 1996. Pada tahun pelajaran 2005/2006, Pondok Pesantren Tapak Sunan menerima siswa/santri baru tingkat RA Madrasah Diniyah dan bagi siswa MTs dan MA seluruh siswanya wajib diasramakan. Program Pendidikan yang diselenggarakan oleh Pondok Pesantren Tapak Sunan adalah:

\section{Pendidikan Salafiyah}

Pendidikan Salafiyah/ Madrasah Islamiyah Salafiyah (MIS) Pondok Pesantren Tapak Sunan adalah madrasah informal yang mengelola pengajian santri/ Kegiatan Belajar Mengajar pengajian santri. MIS menggunakan sistem klasikal dengan jenjang pendidikan selama enam tahun dengan kurikulum berbasis As Salafi 2006. KBK As Salafi adalah kurikulum yang disusun melalui proses diskusi mendalam antara Pimpinan dan Asatidz Pondok Pesantren Tapak Sunan untuk meningkatkan relevansi dan kualitas pendidikan. MIS juga mengeluarkan ijazah bagi santri yang telah menempuh pendidikan selama enam tahun dan lulus dalam ujian akhir MIS. Ijazah tersebut dapat digunakan untuk mendaftar di berbagai Perguruan Tinggi Islam, seperti UIN Syarif Hidayatullah Jakarta, Universitas Islam Jakarta, Universitas At Thahiriyah, dan lain-lain.

\section{Pendidikan Formal}
a. Taman Kanak-kanak Islam
b. Madrasah Diniyah
c. Madrasah Tsanawiyah Akreditas A
d. Madrasah Aliyah (MA) Akreditas B
(MTs)

Kerangka Berfikir. Segala aktivitas yang dilakukan oleh manusia memerlukan oksigen dalam pembentukkan energinya. Untuk menyebarkan oksigen tersebut diperlukan hemoglobin untuk mengikat oksigen dan membawanya ke jaringan ditubuh kita. Hemoglobin berfungsi mengangkut $\mathrm{O}_{2}$ dari paru-paru ke seluruh tubuh. Suatu proses biokimiawi yang penting dalam sel adalah proses pembakaran zat-zat gizi tertentu untuk menghasilkan energi. Dalam proses tersebut sel memerlukan $\mathrm{O}_{2}$ untuk mengikat atom $\mathrm{CO}_{2}$ dan $\mathrm{H}_{2}$ yang terlepas dalam proses pembakaran menjadi $\mathrm{CO} 2$ dan $\mathrm{H} 2 \mathrm{O}$ yang harus dibuang melalui darah merah ke paruparu. Sampai di paru-paru darah merah melepas $\mathrm{O} 2$ yang kotor dan mengikat kembali $\mathrm{O}_{2}$ bersih untuk diangkut ke sel-sel jaringan dan seterusnya.

Hemoglobin adalah sebuah protein yang berada pada sel darah merah, yang dapat bergabung dengan oksigen dan berfungsi membawa atau mengirimkan oksigen dari paru-paru menuju jaringanjaringan tubuh.

Sedangkan kapasitas aerobik maksimal adalah tempo tercepat dimana seseorang dapat menggunakan oksigen selama olahraga atau kemampuan untuk mengambil oksigen selama kerja fisik diukur dalam satuan $\mathrm{ml} / \mathrm{kg} . \mathrm{bb} / \mathrm{menit}$.

Kadar hemoglobin yang baik diperlukan dalam melakukan suatu aktifitas jasmani seperti olahraga. Karena pada saat seseorang melakukan aktivitas fisik, semua sel dalam tubuh bekerja pula. Untuk melakukan pekerjaan tersebut membutuhkan oksigen. Oksigen yang dihirup kedalam tubuh disebarkan ke berjuta sel-sel tubuh. Untuk menyebarkan oksigen tersebut dibutuhkan hemoglobin untuk mengikat oksigen dan membawanya ke berbagai jaringan di tubuh kita. Jadi diduga semakin banyak pula oksigen yang dapat diangkut, sehingga kapasitas aerobik maksimal juga meningkat.

\section{METODE}

Berdasarkan rumusan masalah penelitian ini bertujuan untuk mengetahui bagaimana hubungan antara kadar hemoglobin $(\mathrm{Hb})$ dengan kapasitas aerobik maksimal pada santri Pondok Pesantren Tapak Sunan Jakarta.

Insrumen Penelitian. Data dilakukan dengan melakukan beberapa tes atau pengukuran 
1. Pengukuran Kadar Hemoglobin dengan menggunakan Haemometer

2. Pengukuran Kapasitas Aerobik Maksimal dilakukan dengan menggunakan metode Bleep Test

Teknik Pengumpulan Data. Sesuai dengan variabel yang disusun dalam penelitian, maka fasilitas dan alat untuk pengumpulan data adalah sebagai berikut:

1. Test Kadar Hemoglobin

Alatnya: hemoglobin meter test dan stik hemoglobin, cairan pelarut, jarum, kapas, dan alkohol. ${ }^{2}$

2. Test Kapasitas Aerobik

Fasilitas dan alatnya: lintasan datar dan tidak licin, meteran, kaset, kerucut,serta stopwatch. ${ }^{3}$

Cara pengukuran:

1. Ukurlah jarak 20 meter dan berilah tanda dengan pita dan pembatas jarak

2. Instrusikan kepada testi untuk lari kearah ujung/akhir yang berlawanan dan sentuhkan satu kaki dibelakang garis batas pada saat terdengar bunyi "tuut".

3. Apabila testi telah sampai sebelum bunyi "tuut", testi harus bertumpu pada titik putar, menanti tanda bunyi, kemudian lari kearah garis yang berlawanan agar supaya dapat mencapai tepat pada saat tanda berikutnya berbunyi.

4. Pada akhir dari tiap menit interval waktu diantara dua bunyi "tuut" makin pendek, oleh karena itu, kecepatan lari makin bertambah cepat.

5. Testi harus dapat mencapai garis ujung pada waktu yang ditentukan dan tidak terlambat. Tekankan kepada testi agar berputar dan lari kembali, bukannya lari membuat beloka melengkung,

karena akan memakan lebih banyak waktu.

6. Tiap testi harus berlari selama mungkin sehingga testi tidak dapat lagi mengejar tanda bunyi "tuut" dari pita rekaman. kriteria untuk menghentikan testi adalah apabila testi tertinggal tanda bunyi "tuut" dua kali lebih dari dua langkah dibelakan garis ujung.

\section{HASIL DAN PEMBAHASAN}

Deskripsi Data. Deskripsi data pada penelitian ini dimaksudkan untuk memperoleh gambaran mengenai penyebaran data meliputi nilai tertinggi, nilai terendah, rata-rata, simpangan baku, varian, distribusi frekuensi, serta histogram dari masing-masing variabel $\mathrm{X}$ maupun Y. Berikut data lengkapnya:

\section{Tabel 1.}

Deskripsi Data Penelitian Kadar Hemoglobin (Hb) dan Kapasitas Aerobik Maksimal (VO2 MAX) Santri Pondok Pesantren Tapak Sunan Jakarta. Minggu, 18 November 2012

\begin{tabular}{c|c|c}
\hline Variabel & $\begin{array}{c}\text { Kadar } \\
\text { Haemoglobin } \\
\text { gr/dl }\end{array}$ & $\begin{array}{c}\text { Kapasitas Aerobik } \\
\text { Maksimal } \\
\text { Ml/kg.BB/ } \\
\text { menit }\end{array}$ \\
\hline $\begin{array}{c}\text { Nilai } \\
\text { Tertinggi }\end{array}$ & 13.6 & 41.8 \\
\hline $\begin{array}{c}\text { Nilai } \\
\text { Terendah }\end{array}$ & 10.8 & 30.2 \\
\hline Rata-rata & 11.62 & 36.55 \\
\hline $\begin{array}{c}\text { Simpangan } \\
\text { Baku }\end{array}$ & $\mathbf{0 . 6 1 7}$ & 3.354 \\
\hline Varians & $\mathbf{0 . 3 8 1}$ & 11.249 \\
\hline
\end{tabular}

Sumber: Hasil pengolahan data

1. Data Kadar Hemoglobin (X)

Hasil penelitian menunjukkan Kadar Hemoglobin (X) diperoleh rentang dari 10.8 hingga 13.6 dengan nilai rata-rata 11.62 serta simpangan baku sebesar 0.617 dan varian sebesar 0.381. Di bawah ini disajikan distribusi frekuensi dan grafik histogram Kadar Hemoglobin.

\section{Tabel 2.}

Distribusi Frekuensi Kadar Hemoglobin

\begin{tabular}{|c|c|c|c|c|}
\hline \multirow[b]{2}{*}{$\mathrm{NO}$} & \multirow{2}{*}{$\begin{array}{l}\text { Kelas } \\
\text { Interval }\end{array}$} & \multirow{2}{*}{$\begin{array}{c}\text { Titik } \\
\text { Tengah }\end{array}$} & \multicolumn{2}{|c|}{ Frekuensi } \\
\hline & & & Absolut & Relatif (\%) \\
\hline 1 & $10.8-11.2$ & 11 & 6 & $24 \%$ \\
\hline 2 & $11.3-11.7$ & 11.5 & 5 & $20 \%$ \\
\hline 3 & $11.8-12.2$ & 12 & 9 & $36 \%$ \\
\hline 4 & $12.3-12.6$ & 12.45 & 2 & 8 \\
\hline 5 & $12.7-13.1$ & 12.9 & 1 & 4 \\
\hline 6 & $13.2-13.6$ & 13.4 & 2 & 8 \\
\hline & & $\mathbf{j}$ & 2 & $100 \%$ \\
\hline
\end{tabular}

Sumber: Hasil Pengolahan Data 
Berdasarkan tabel 2 diatas dibandingkan dengan nilai rata- rata, terlihat testee yang berada pada kelas rata-rata sebanyak 9 testee $(36 \%)$ dan di bawah kelas rata-rata sebanyak 11 testee $44 \%$ ) sedangkan yang berada di atas kelas rata-rata sebanyak 5 testee $(20 \%)$.

\section{Data Kapasitas Aerobik Maksimal (Y)}

Hasil pengukuran menunjukkan Kapasita Aerobik Maksimal (Y) diperoleh rentang dari 30.20 hingga 41.80 dengan nilai rata-rata sebesar 36.55 serta simpangan baku sebesar 3.354 dan varian sebesar 11.249. Dibawah ini disajikan distribusi frekuensi dan grafik histogram Kapasitas Aerobik Maksimal.

Tabel. 3

Distribusi Frekuensi Kapasitas Aerobik Maksimal

\begin{tabular}{c|c|c|c|c}
\multirow{2}{*}{ NO } & \multirow{2}{*}{$\begin{array}{c}\text { Kelas } \\
\text { Interval }\end{array}$} & $\begin{array}{c}\text { Titik } \\
\text { Tengah }\end{array}$ & \multicolumn{2}{|c}{ Frekuensi } \\
\cline { 4 - 5 } & $30.2-32.13$ & 31.16 & 3 & $12 \%$ \\
\hline 1 & 30 Absolut & $\begin{array}{c}\text { Relatif } \\
(\%)\end{array}$ \\
\hline 2 & $32.14-34.06$ & 33.1 & 4 & $16 \%$ \\
\hline 3 & $34.07-35.99$ & 35.03 & 4 & $16 \%$ \\
\hline 4 & $36.00-37.92$ & 36.96 & 5 & $20 \%$ \\
\hline 5 & $37.93-39.85$ & 38.89 & 2 & $8 \%$ \\
\hline 6 & $39.86-41.80$ & 40.83 & 7 & $28 \%$ \\
\hline & \multicolumn{2}{|c|}{$\mathbf{j}$} & $\mathbf{2 5}$ & $\mathbf{1 0 0 \%}$
\end{tabular}

Berdasarkan tabel 3 diatas dibandingkan dengan nilai rata- rata, terlihat testee yang berada pada kelas rata-rata sebanyak 5 testee $(20 \%)$ dan yang berada dibawah kelas rata-rata sebanyak 11 testee (48\%), sedangkan yang berada diatas kelas rata-rata sebanyak 9 testee $(36 \%)$.

\section{PENUTUP}

Kesimpulan. Berdasarkan hasil penelitian yang terdapat pada bab IV, maka dapat disimpulkan bahwa Terdapat Hubungan yang bermakna antara Kadar Hemoglobin Dengan Kapasitas Aerobik Maksimal pada Santri Pondok Pesantren Tapak Sunan Jakarta.
Saran.

1. Diharapkan agar bagian kesehatan di pondok pesantren selalu memperhatikan, mengontrol kesehatan dan melakukan pengukuran terhadap kadar hemoglobin secara berkala kepada Santri-santri Tapak Sunan. Karena Kadar Hemoglobin merupakan salah satu faktor penting dalam menentukan Kapasitas Aerobik Maksimal Santri, sehingga dengan Kapasitas Aerobik Maksimal yang baik memungkinkan seorang Santri dapat beraktifitas lebih baik didalam lingkungan pondok pesantren, apa lagi seorang atlet pondok pesantren.

2. Segala program latihan olahraga dipondok pesantren yang diberikan hendak diatur secara terprogram dan sistematis lagi, supaya program latihan yang dijalankan dapat terkontrol dengan baik dan dapat mencapai prestasi yang diinginkan.

3. Pengurus Pondok Pesantren dan guruguru hendaknya memberikan dukungan sosial dan material yang lebih kepada para santri, agar mereka bisa meningkatkan kesegaran jasmani mereka.

\section{DAFTAR RUJUKAN}

Arie S. Sutopo dan Alma Permana Lestari, Buku Penuntun Praktikum Ilmu Faal Kerja, (Jakarta: FIK UNJ, Edisi 2/2001 )

Astrand P, dan Rodhal K, Text Book of Work Physiology International Student Edition. Sydney: 1970

Basuki Soedjono, Anatomi dan Fisiologi Manusia, (Jakarta: Depdikbud, 2008)

Brian J Sharkey, Kebugaran dan Kesehatan, (Jakarta: Grafindo, 2000)

Depdiknas, Pedoman dan Modul Pelatihan Kesehatan Olahraga Bagi Pelatih Olahragawan Pelajar, (Jakarta: Depdiknas, 2000)

Gabe Mirkin dan Marshall Hoffman, Kesehatan Olahraga, terjemahan Sadoso Sumasardjuno, (Jakarta: PT. Grafidian Jaya, 1984)

Ganong, F. William, Buku

Ajar Fisiologi Kedokteran, (Jakarta: Buku kedokteran ECG, 1999) 
Guyton, Arthur C, Fisiologi Kedokteran, terjemahan Ken Ariata Tengadi dkk, (Jakarta: EGC, 1999)

J. Sharkey, Brian, Kebugaran dan Kesehatan, (Jakarta: PT. Raja Grafindo Perada, 2003)

Lauralee Sherwood, Fisiologi Manusia dari Sel ke Sistem Ed.2. Penerbit: Buku Kedokteran EGC, 1996.

Moeloek, Dangsina Tjokronegoro

Arjatno, Kesehatan Olahraga, (Jakarta: FKUI, 1984)

Pusat Kesegaran Jasmani, Aerobik, (Jakarta: Balai Pustaka, 1975)

Russel Pate, et al. Dasar-Dasar Ilmu Kepelatihan, IKIP

Semarang: Semarang, 1993.

Sudjana, Metoda Statistika, (Bandung: Tarsito, 2002)

Tjaliek Soegardo, Ilmu Faal, (PGSD Penjas Departemen Pendidikan dan Kebudayaan Direktorat Jendral Pendidikan Tinggi, Proyek Pembinaan Tenaga Kependidikan, Jakarta, 1992)

Wahjoedi, Pembudayaan Kesegaran Jasmani, (Majalah Forum Olahraga, September 1999)

Widyastuti, Tes dan Pengukuran Olahraga (Jakarta: PT Bumi Timur Jaya, 2011)

Wahjoedi, Pembudayaan Kesegaran Jasmani, (Majalah Forum Olahraga, September 1999)

Sumber Internet:

http://www.indomedia.com/intisari/2000/ju ni/remaja6.htm. Diakses Tanggal 1 Juni 2012 pukul 23.00 wib 